\title{
Analisis Kelayakan Penerapan RFID pada Fungsi Bisnis Penjualan sebagai Komponen Enterprise Resource Planning
}

\author{
Astrid Lestari Tungadi ${ }^{1}$, Erick Alfons Lisangan ${ }^{2}$ \\ astrid_tungadi@lecturer.uajm.ac.id ${ }^{1}$, erick_lisangan@lecturer.uajm.ac.id ${ }^{2}$
}

\author{
Sistem Informasi, Fakultas Teknologi Informasi, Universitas Atma Jaya Makassar \\ Teknik Informatika, Fakultas Teknologi Informasi, Universitas Atma Jaya Makassar
}

Diterima: 02 Mei 2020 | Direvisi: 25 Mei 2020 | Disetujui: 29 Mei 2020

(c) 2020 Program Studi Sistem Informasi Fakultas Sains dan Teknologi,

Universitas Islam Negeri Raden Fatah Palembang, Indonesia

\begin{abstract}
Abstrak: Salah satu sistem yang dapat diterapkan dalam perusahaan, baik skala kecil hingga berskala besar, adalah sistem Enterprise Resource Planning (ERP). Salah satu komponen yang terdapat pada sistem ERP adalah fungsi bisnis penjualan atau transaksi yang melibatkan perusahaan dengan pelanggan. Pemanfaatan teknologi yang digunakan saat ini untuk mengatasi tumpukan pelanggan adalah teknologi barcode. Teknologi barcode memiliki kekurangan aspek kecepatan dan jarak area identifikasi untuk dalam proses identifikasi setiap label yang terdapat pada setiap barang. Kelemahan dari barcode dapat diatasi dengan menggunakan teknologi RFID, baik yang bersifat Passive maupun Active. Pada penelitian ini akan dilakukan analisis kelayakan penerapan RFID pada fungsi bisnis penjualan di sebuah perusahaan ritel berskala besar. Analisis kelayakan dilakukan dengan melihat dari aspek TELOS dengan melibatkan manajer penjualan, calon pengguna, manajer IT, pelanggan, dan ahli IT sebagai penilai setiap faktor. Nilai akhir TELOS sebesar 8.2 menunjukkan bahwa teknologi RFID dapat diterapkan pada fungsi bisnis penjualan di masa depan.
\end{abstract}

Kata Kunci: RFID, fungsi bisnis penjualan, analisis kelayakan TELOS

\begin{abstract}
The system that can be applied in companies, both small and large scale, is the Enterprise Resource Planning (ERP) system. A component contained in the ERP system is the business function of sales or transactions involving companies with customers. The utilization of technology that is used today to overcome customer stacks is barcode technology. Barcode technology had lack of speed and distance to identification each label on each item. The weaknesses of barcodes can be overcome by using RFID technology, both Passive and Active RFID. In this study, a feasibility analysis will be conducted to applying RFID in the sales business function at a large-scale retail company. The feasibility analysis is done by looking at aspects of TELOS by involving sales managers, potential users, IT managers, customers, and IT experts as assessors of each factor. The TELOS final score of 8.2 indicates that RFID technology can be applied to the sales business function in the future
\end{abstract}

Keywords: RFID, sales business process, TELOS feasibility analysis

\section{PENDAHULUAN}

Sistem Enterprise Resource Planning (ERP) merupakan software yang bertugas untuk mengintegrasikan, mengatur, mengelola, serta mengotomatisasi sebagian besar proses pada sebuah organisasi bisnis (Ruhi \& Ghatrenabi, 2016). ERP merupakan salah satu cara untuk mengelola sumber daya perusahaan dengan memanfaatkan teknologi informasi. Penggunaan ERP yang dilengkapi dengan hardware dan software dapat membantu menghasilkan pengambilan keputusan yang cepat karena menyediakan analisa dan laporan dengan cepat (Verdi, 2013). Salah satu fungsional bisnis yang didukung oleh ERP adalah fungsi bisnis penjualan. Fungsi bisnis penjualan memiliki peranan yang penting pada sebuah perusahaan, baik skala kecil maupun besar. Hal ini disebabkan karena pada fungsi bisnis penjualan terjadi interaksi langsung perusahaan dan pelanggan (Tungadi et al., 2019). 
Sistem perbelanjaan yang digunakan pada perusahaan saat ini sebagian besar memanfaatkan teknologi barcode. Teknologi barcode memiliki beberapa kelemahan dalam mengidentifikasikan label barang, seperti aspek kecepatan dan jarak area identifikasi (Pradipta, 2014). Permasalahan klasik yang sering dihadapi oleh perusahaan terkait fungsi bisnis penjualan adalah terjadinya antrian walaupun telah memanfaatkan teknologi barcode. Hal ini dapat disebabkan karena proses identifikasi pada teknologi barcode dilakukan satu persatu dan menggunakan sistem line of sight dimana reader harus melihat label secara langsung agar dapat mengidentifikasikan label barcode (R.T. White et al., 2007). Salah satu teknologi yang dapat digunakan untuk mengatasi kelemahan dari teknologi barcode adalah dengan memanfaatkan teknologi Radio Frequency Identification (RFID). Penggunaan RFID dapat digunakan pada saat proses pengelolaan barang maupun pengidentifikasian barang jika dibutuhkan namun dalam hal pengaplikasiannya pada supermarket belum memungkinkan (Winda, 2009).

Beberapa penelitian telah memanfaatkan simulasi penerapan RFID, baik Passive RFID maupun Active RFID, pada supermarket seperti pada (Tungadi et al., 2019), serta (Tungadi \& Lisangan, 2019). Pada (Tungadi et al., 2019) telah melakukan simulasi penggunaan Passive RFID dengan memanfaatkan Arduino Uno serta terintegrasi dengan sistem POS. Hasil penelitian menunjukkan RFID dapat membantu proses penginputan pada sistem $P O S$ dan bersifat low-cost investment. Kelemahan yang diperoleh pada penelitian tersebut adalah jarak baca yang hanya maksimal $2.5 \mathrm{~cm}$. Hal ini disebabkan karena penggunaan frekuensi $R F I D$ yang rendah, yaitu $13.56 \mathrm{MHz}$.

Pada (Tungadi \& Lisangan, 2019) telah melakukan simulasi penggunaan Active RFID yang terintegrasi dengan sistem $P O S$. Hasil penelitian menunjukkan bahwa proses transaksi dapat dilakukan secara otomatis dan beban kerja kasir dapat berkurang dan diharapkan dapat mempercepat proses transaksi pelanggan untuk mencegah terjadinya antrian. Penelitian tersebut memanfaatkan penggunaan Arduino Uno, modul XD-FST serta XD-RF.

Penerapan RFID saat ini belum dimanfaatkan pada fungsi bisnis penjualan tetapi tidak menutup kemungkinan akan diterapkan di masa depan. Dikarenakan belum diimplementasikannya teknologi $R F I D$ maka dibutuhkannya sebuah studi kelayakan. Studi kelayakan bertujuan untuk menilai secara objektif dan rasional kelayakan suatu proyek atau pengembangan sistem. Selain itu, studi kelayakan juga dapat menentukan kekuatan, kelemahan, peluang, dan ancaman yang ada di lingkungan pengguna, serta sumber daya yang diperlukan untuk implementasi dan peluang berhasilnya sistem yang akan dikembangkan (Justis \& Kreigsmann, 1979).

Salah satu metode analisis atau studi kelayakan yang banyak digunakan adalah pendekatan TELOS. Analisis kelayakan menggunakan pendekatan TELOS melihat sebuah proyek atau pengembangan sistem dari sisi Technical, Economic, Legal, Operational, dan Schedule (Hall, 2011). Penggunaan analisis TELOS digunakan untuk mengetahui tingkat kelayakan implementasi sebuah sistem, seperti pada (Syaifullah \& Widianto, 2014) (Drljaca \& Latinovic, 2018). Pada (Syaifullah \& Widianto, 2014) dilakukan penilaian kelayakan sistem informasi akademik dengan menggunakan TELOS. Sedangkan pada (Drljaca \& Latinovic, 2018) menggunakan TELOS sebagai penilaian kelayakan terhadap perencanaan audit sistem informasi. Pada penelitian ini akan dilakukan analisis atau studi kelayakan terhadap penerapan RFID pada fungsi bisnis penjualan dengan menggunakan pendekatan TELOS. Studi kasus yang digunakan sebagai simulasi implementasi $R F I D$ adalah sebuah perusahaan ritel berskala besar. Analisis kelayakan dilakukan untuk mengetahui apakah penerapan RFID pada fungsi bisnis penjualan layak atau tidak untuk diterapkan di masa depan mengingat saat ini $R F I D$ belum dikembangkan dan diimplementasikan di perusahaan. 


\section{METODOLOGI PENELITIAN}

\subsection{Enterprise Resource Planning}

Enterprise Resource Planning (ERP) adalah sistem perusahaan yang meliputi semua fungsi yang terdapat di dalam perusahaan yang didorong oleh beberapa modul software yang terintegrasi untuk mendukung proses bisnis internal perusahaan. Sebagai contoh, software ERP untuk perusahaan manufaktur umumnya dimulai dari memproses data yang masuk, melacak status dari penjualan, inventory, pengiriman barang, dan penagihan barang, serta memperkirakan bahan baku dan kebutuhan sumber daya manusia (James A. O'Brien \& Marakas, 2017). Komponen-komponen utama ERP dapat dilihat pada Gambar 1.

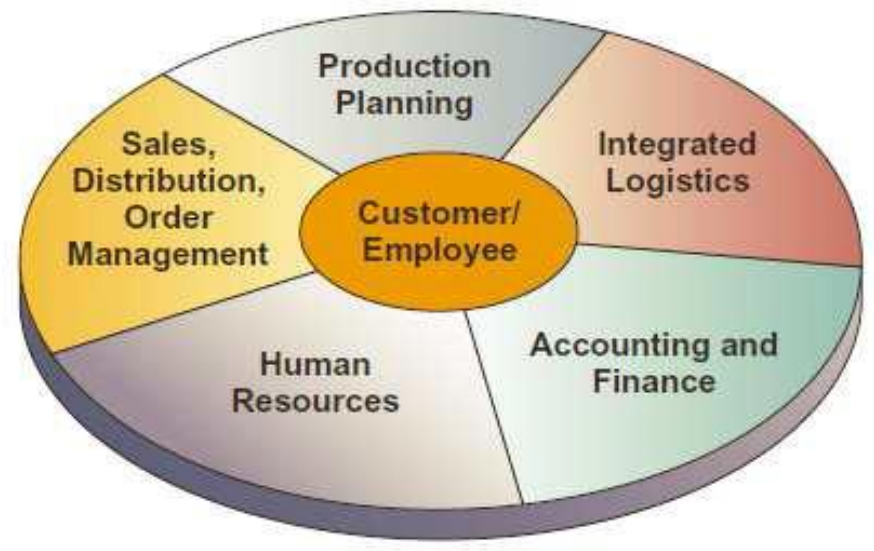

\section{Gambar 1 Komponen Utama ERP}

\subsection{Radio Frequency Identification}

Radio Frequency Identification (RFID) merupakan sebuah teknologi compact wireless yang diunggulkan untuk mentransformasi dunia komersial. RFID adalah sebuah teknologi yang memanfaatkan frekuensi radio untuk identifikasi otomatis terhadap objek-objek atau manusia. Tag RFID adalah transponder kecil yang menanggapi query dari reader dengan mentransmisikan nomor identifikasi. RFID banyak digunakan untuk melacak barang-barang di lingkungan produksi dan untuk melabeli barang-barang di supermarket (Jechlitschek, 2013). Cara kerja sistem RFID dapat dilihat pada Gambar 2.

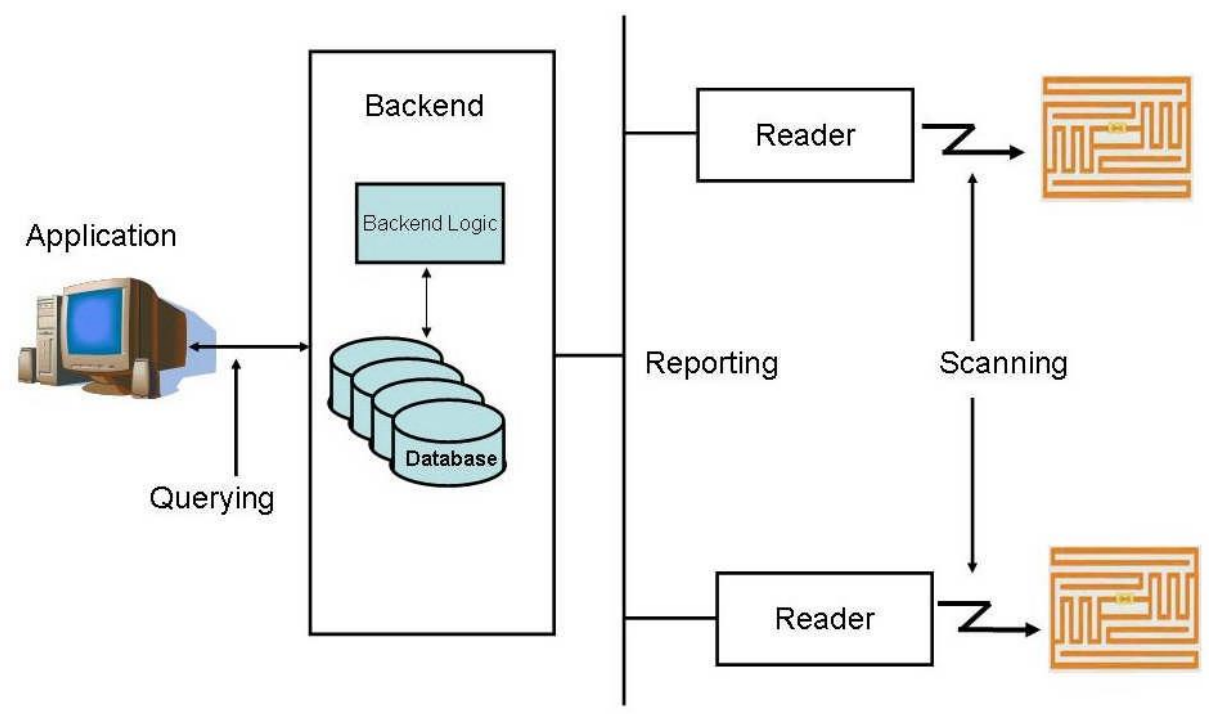




\section{Gambar 2 Cara Kerja Sistem RFID}

\subsection{Integrasi RFID pada Fungsi Bisnis Penjualan}

Pada penelitian (Tungadi et al., 2019) dan (Tungadi \& Lisangan, 2019) menghasilkan simulasi penggunaan Passive RFID dan Active RFID pada perusahaan ritel. Pada penelitian tersebut, terdapat perubahan fungsi pegawai kasir yang dari sebelumnya melakukan penginputan data ke sistem Point of Sale (POS) menjadi pengecekan daftar pembelian pelanggan. Pada sistem yang dirancang, pelanggan bertugas untuk melakukan scanning hasil perbelanjaannya dan secara otomatis akan dideteksi oleh sistem. Use case diagram dapat dilihat pada Gambar 3.

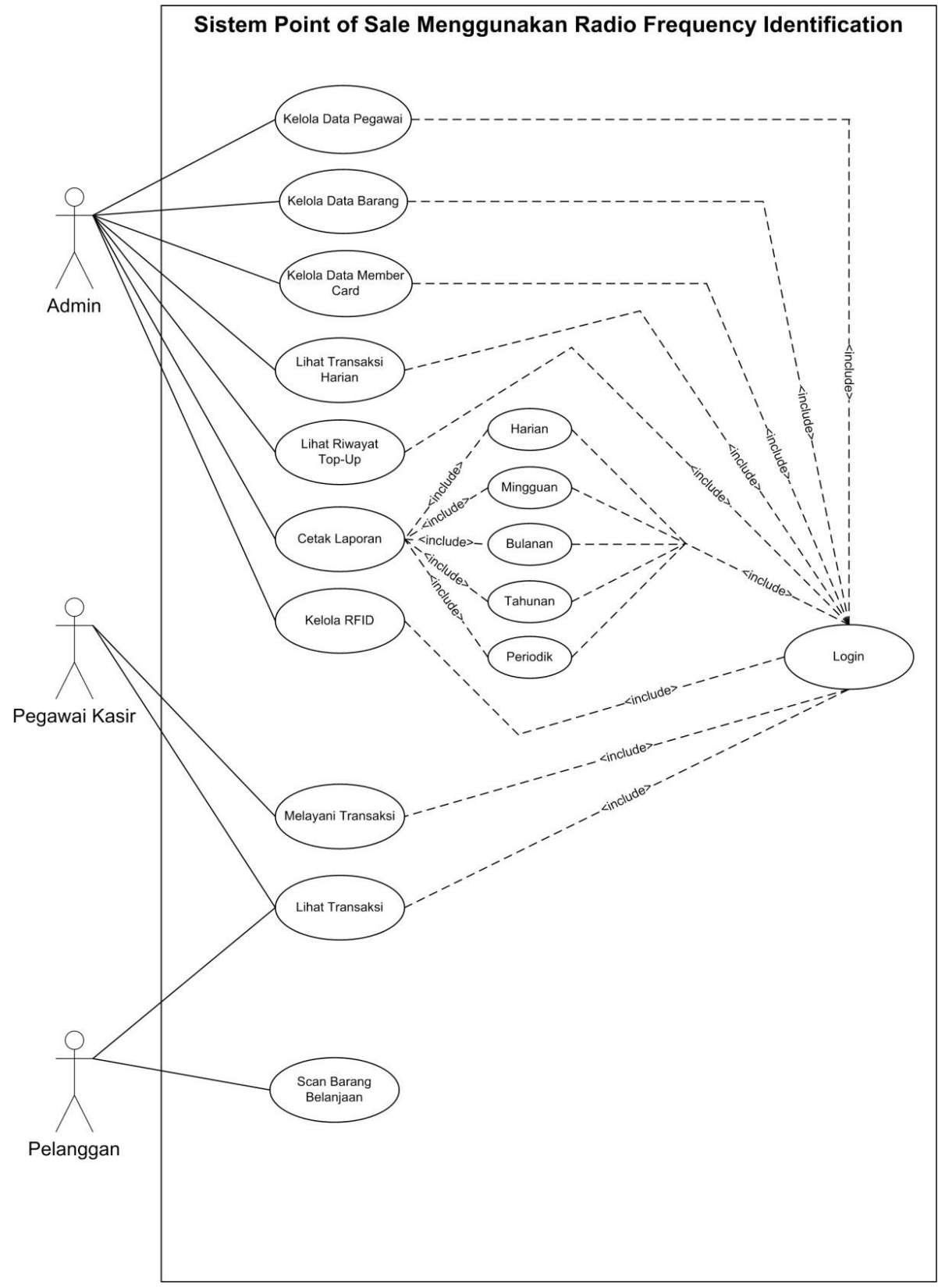

Gambar 3 Use case diagram Sistem POS berbasis RFID 


\subsubsection{Sistem POS berbasis Passive RFID}

Pada Gambar 4, dapat dilihat tampilan aplikasi POS berbasis Passive RFID. Secara umum, aplikasi $P O S$ yang dirancang memiliki fungsi yang sama dengan aplikasi $P O S$ pada umumnya. Aplikasi $P O S$ tersebut bertujuan untuk melayani transaksi yang dilakukan oleh pelanggan. Perbedaan utama terletak pada proses identifikasi barang dimana prosesnya dilakukan secara langsung melalui RFID tag barang belanjaan yang dimiliki oleh pelanggan.

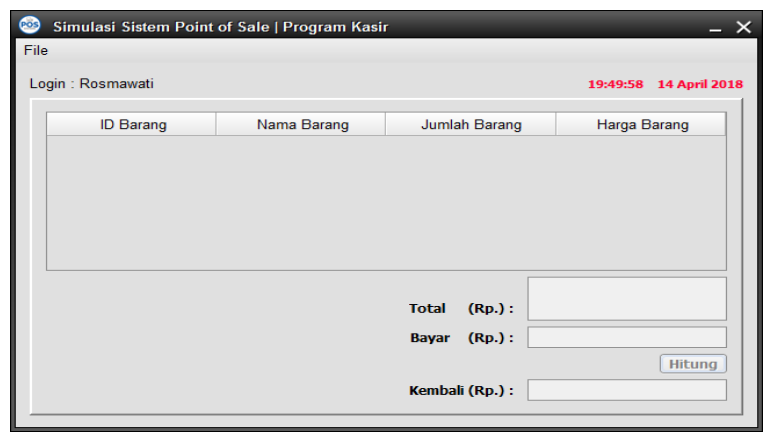

\section{Gambar 4 Tampilan Sistem POS berbasis Passive RFID}

Ketika sebuah barang yang memiliki RFID tag di-scan pada RFID Reader maka aplikasi akan membaca ID dari RFID dan mengidentifikasi dengan melakukan pengecekan apakah data barang tersebut terdapat dalam database atau tidak. Apabila tersedia, sistem akan menyimpan transaksi barang dan menampilkan total transaksi belanja pelanggan (Gambar 5). Setelah seluruh barang belanjaan pelanggan di-scan dan diidentifikasi, langkah selanjutnya adalah pembayaran transaksi pelanggan. Proses pembayaran memiliki 2 (dua) opsi, yaitu pembayaran secara tunai atau menggunakan member card. Member card yang dimiliki oleh pelanggan berbasis RFID sehingga pelanggan cukup men-scan member card pada RFID Reader dan mengurangi saldo yang dimiliki oleh pelanggan (Gambar 6).

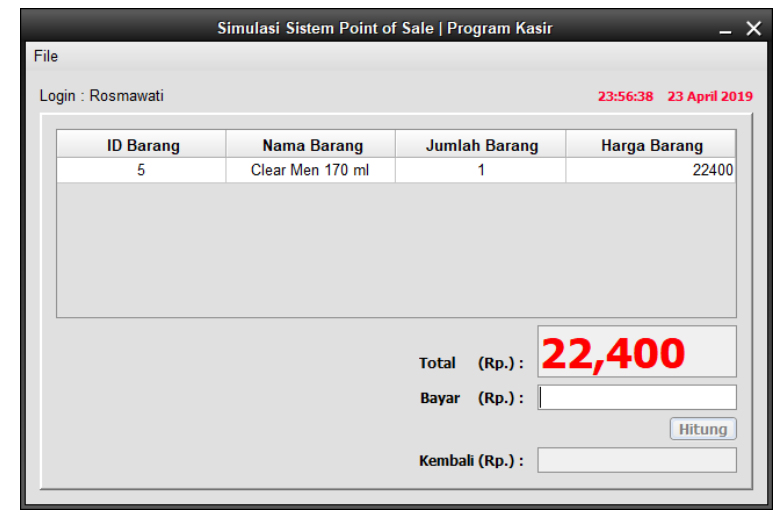

Gambar 5 Tampilan transaksi pelanggan

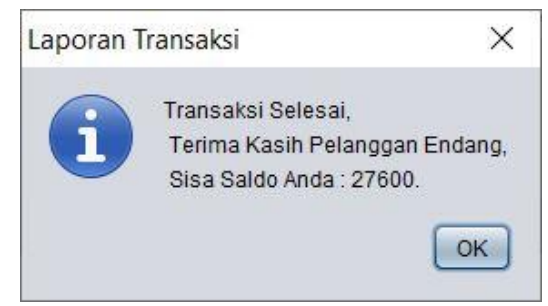

Gambar 6 Tampilan pembayaran transaksi menggunakan member card 


\subsubsection{Sistem POS berbasis Active RFID}

Alur kerja sistem POS berbasis Active RFID dapat dilihat pada Gambar 7, dimana terdapat 3 (tiga) komponen utama. Ketiga komponen tersebut adalah pelanggan, tablet $P O S$ yang dilengkapi dengan Active RFID receiver, dan server penyimpanan data. Perangkat tablet $P O S$ dan server saling berkomunikasi melalui koneksi wireless.
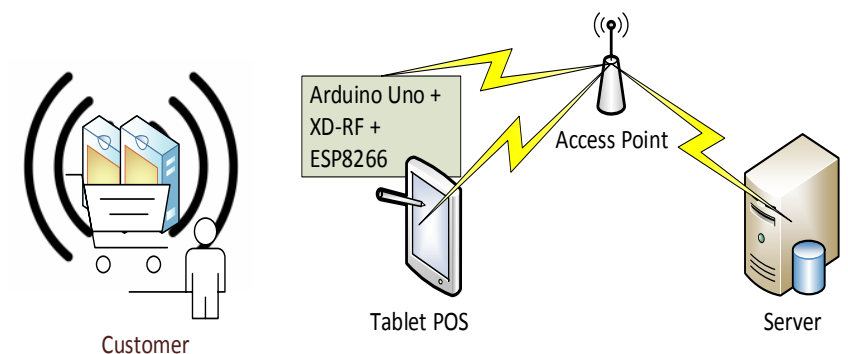

\section{Gambar 7 Workflow Sistem POS berbasis Active RFID}

Sama seperti sistem POS berbasis Passive RFID, sistem tablet POS berbasis Active RFID juga memiliki fungsi yang sama dengan barang $P O S$ pada umumnya. Tampilan awal dapat dilihat pada Gambar 8. Ketika sebuah item yang diwakili dengan alat transmitter melewati receiver maka receiver akan mengirimkan data ke server untuk dilakukan proses identifikasi. Data yang dikirimkan berisi berupa IP kasir dan kode batch transmitter yang mewakili barang.

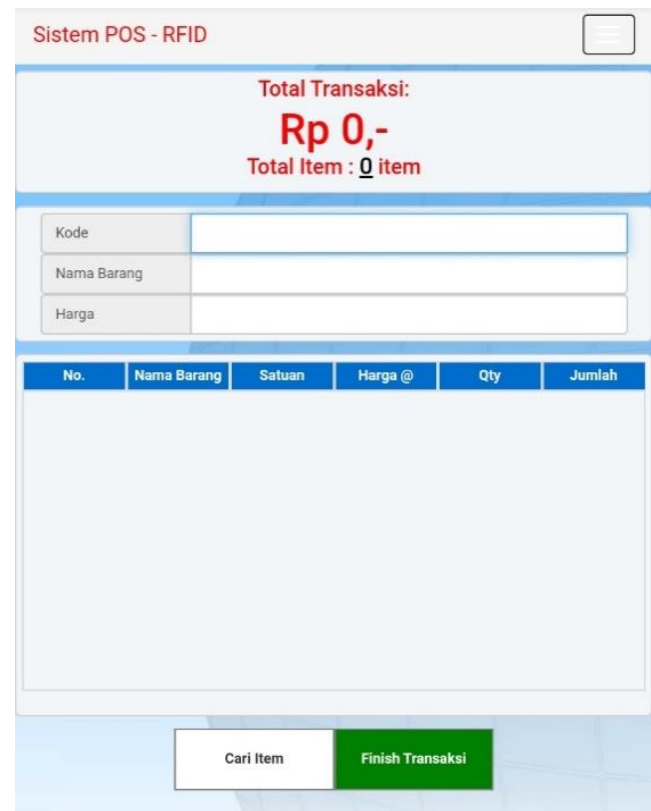

\section{Gambar 8 Tampilan Awal Sistem POS berbasis Active RFID}

Server akan menerima dan mengidentifikasikan kode batch yang dikirim untuk mengetahui apakah data barang tersebut tersedia atau tidak. Apabila tersedia, maka sistem memasukkan ke dalam transaksi pelanggan untuk kemudian dilakukan perhitungan total transaksi (Gambar 9). Setelah seluruh barang belanjaan pelanggan di-scan maka pelanggan melakukan pembayaran menggunakan member card. Kasir kemudian akan melakukan pengecekan barang belanjaan dan kemudian dilakukan penyelesaian transaksi. Sistem kemudian akan menampilkan sisa saldo serta dan mencetak struk belanja pelanggan secara otomatis (Gambar 10). 


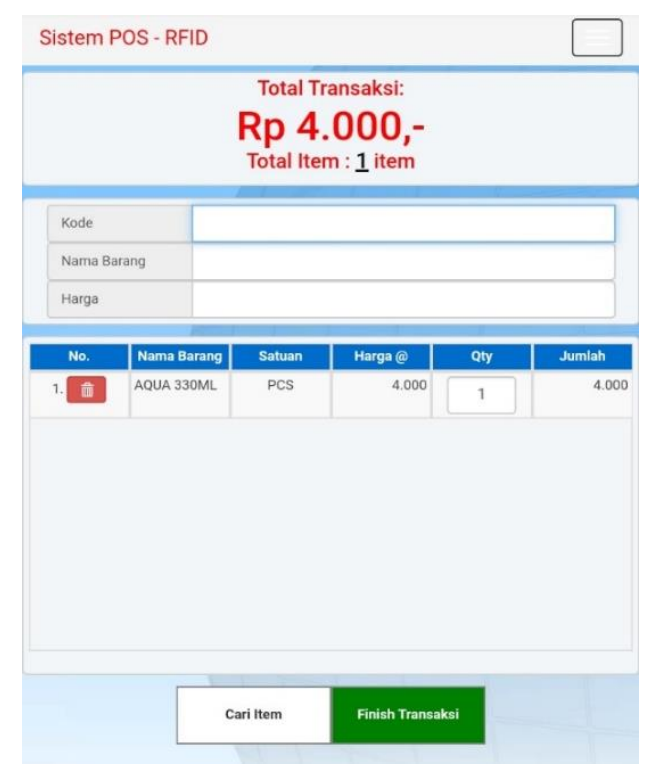

Gambar 9 Tampilan Deteksi Tag RFID Item

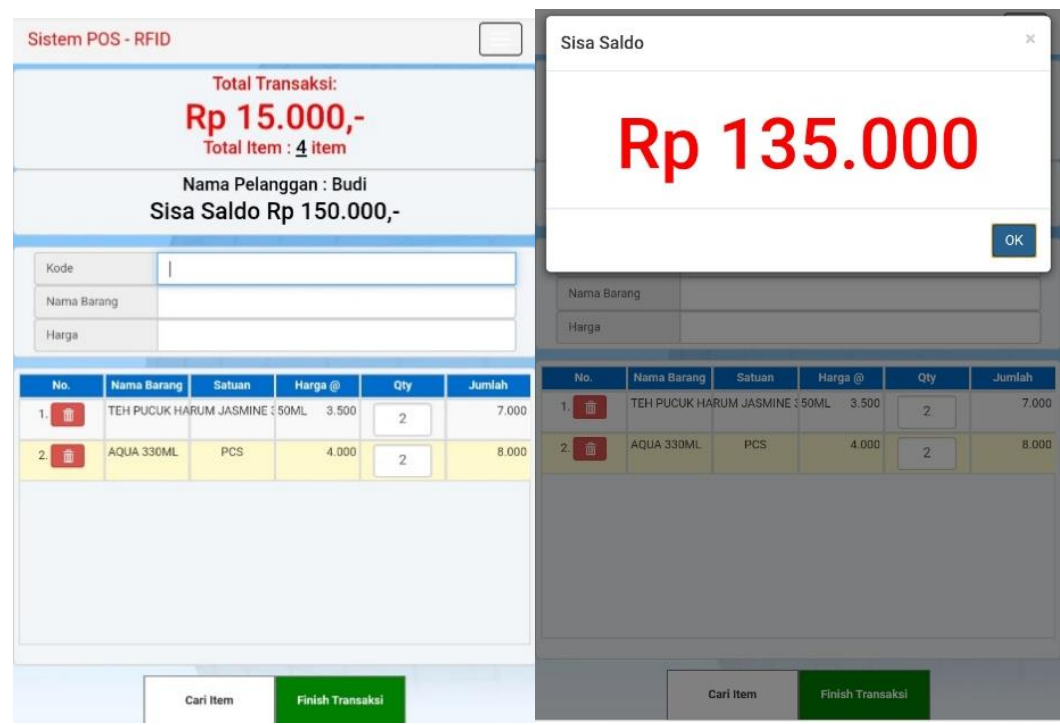

Gambar 10 Tampilan Informasi dan Sisa Saldo Pelanggan

\section{HASIL DAN PEMBAHASAN}

Analisis kelayakan TELOS terhadap kelayakan implementasi RFID pada fungsi bisnis penjualan dilakukan secara kualitatif dan kuantitatif. Hasil penemuan selama perancangan sistem akan dijadikan sebagai masukan secara kualitatif. Sedangkan proses penilaian (scoring) kelayakan TELOS dilakukan secara kuantitatif. Dalam melakukan penilaian (scoring) terhadap kelayakan implementasi RFID melibatkan 2 (dua) pihak, yaitu pihak internal dan eksternal perusahaan. Sebagai perwakilan pihak internal, yaitu manajer penjualan, calon pengguna (kasir), serta staff IT perusahaan. Sedangkan untuk pihak eksternal perusahaan melibatkan konsumen dan ahli IT. Proses penilaian dilakukan dengan menggunakan proses wawancara kemudian dilakukan pengambilan rata-rata terhadap jawaban responden untuk setiap komponen TELOS. 


\subsection{Kelayakan Teknis}

Analisis kelayakan dari sisi teknis atau teknologi dilakukan dengan melihat kelayakan RFID dari sisi teknologi. Pembahasan dari teknologi yang dibahas adalah penggunaan tag $R F I D$ pada setiap produk yang nantinya dipasangkan sebagai bentuk pengidentifikasian pada produk tersebut. Dalam menilai kelayakan teknik dilakukan scoring dengan syarat apabila sistem yang akan diterapkan telah menggunakan teknologi yang sudah ada atau telah dipakai secara umum dan diketahui oleh manajemen maka nilai untuk kelayakan teknik antara 9.5 sampai dengan 10. Jika sebaliknya teknologi yang dipakai merupakan teknologi baru dan belum dipakai secara umum, sehingga membutuhkan keluaran terbaru, maka nilai untuk kelayakan teknik antara 6 sampai dengan 8 (Syaifullah \& Widianto, 2014).

\subsubsection{Passive RFID}

Pada Gambar 11, menunjukkan Square Paper RFID Tag yang berfrekuensi pada 13.56 MHz dan berdiameter $43 \mathrm{~mm}$ x $43 \mathrm{~mm}$. RFID tag bertipe label dapat digunakan pada penelitian ini dikarenakan pemasangannya lebih mudah bila dibandingkan dengan RFID tag bertipe lain, $R F I D$ ini juga dapat di-read dan write sehingga memungkinkan untuk melakukan perubahan ID tag. Square Paper RFID Tag adalah tag yang memiliki bentuk seperti stiker sehingga untuk memasangnya pada produk hanya perlu meletakkannya saja pada produk tersebut. Setiap produk yang telah terpasang Square Paper RFID Tag memiliki ID tag unik yang menjadi penanda produk tersebut ketika teridentifikasi oleh RFID Reader.

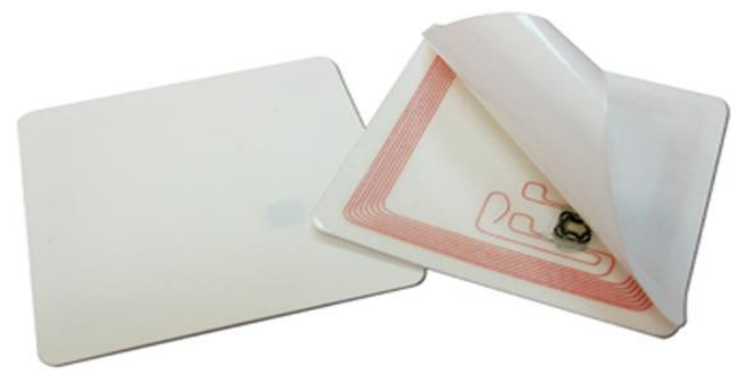

Gambar 11 RFID Tag Tipe Label

Produk yang telah diberikan label RFID Tag tidak dapat teridentifikasi tanpa adanya sebuah RFID Reader. RFID Reader merupakan alat yang memiliki fungsi khusus untuk membaca sinyal dari gelombang radio yang dipancarkan oleh RFID Tag, sehingga diperlukan sebuah alat pembaca sinyal gelombang radio yang dipancarkan oleh RFID Tag yaitu RFID Reader yang memiliki frekuensi $13.56 \mathrm{MHz}$. Pada Gambar 12, menunjukkan modul RFID-RC522, RFID Reader tersebut memiliki frekuensi yang sama dengan RFID Tag sehingga memungkinkan proses pengidentifikasian tag pada produk, RFID Reader ditempatkan di setiap jalur antrian pada loket kasir supermarket.

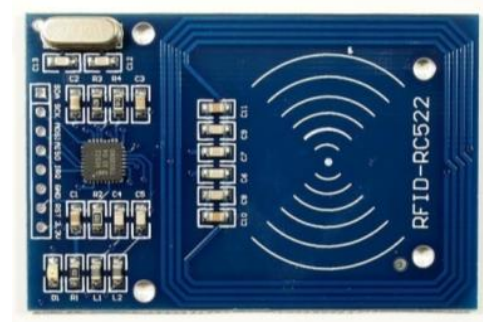

Gambar 12 RFID-RC522 
Penggunaan Arduino Uno sebagai teknologi pendukung untuk membantu mengkomunikasikan RFID Reader dengan komputer kasir, Arduino Uno juga ditempatkan di setiap jalur antrian pada loket kasir supermarket. Perangkat komputer kasir digunakan untuk membantu pegawai kasir dalam melakukan transaksi, menampilkan tampilan visual dari program kasir dan menampilkan informasi dari setiap produk yang telah teridentifikasi oleh RFID Reader. Pada komputer kasir dilengkapi dengan program Point of Sale untuk menampilkan informasi dari setiap produk yang telah teridentifikasi pada layar komputer, mengolah proses transaksi pembayaran dan menampilkan hasil transaksi.

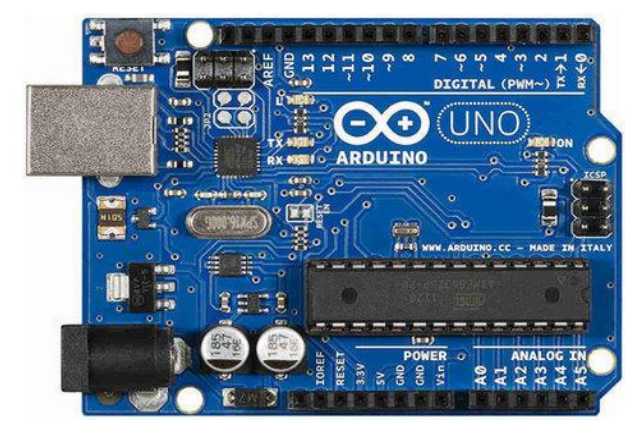

Gambar 13 Arduino Uno

\subsubsection{Active RFID}

Sejauh ini belum dapat ditemukan Active RFID tag dalam bentuk label atau stiker yang bekerja pada frekuensi $315 \mathrm{MHz}$. Alat Active RFID menggunakan modul XD-RF sebagai receiver, serta modul XD-FST sebagai transmitter yang mewakili setiap item barang yang akan dijual. Kedua modul tersebut bekerja pada frekuensi $315 \mathrm{MHz}$.

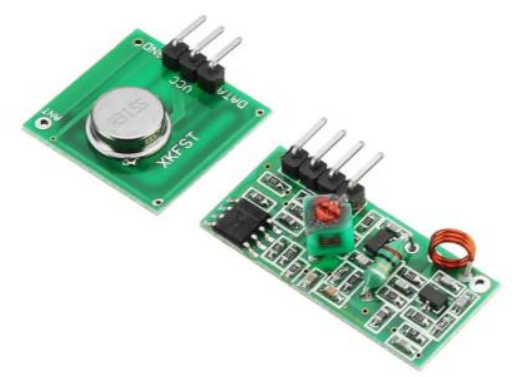

\section{Gambar 14 Modul XD-FST dan XD-RF}

Media komunikasi antara komputer server dan tablet client menggunakan modul ESP 8266. Modul ESP8266 merupakan modul Wifi yang berfungsi sebagai perangkat tambahan mikrokontroler seperti Arduino agar dapat terhubung langsung dengan wifi dan membuat koneksi TCP/IP. ESP8266 memiliki kemampuan on-board processing dan storage yang memungkinkan modul tersebut untuk diintegrasikan dengan sensor-sensor atau dengan aplikasi alat tertentu melalui pin input output dengan menggunakan AT Command. Kelebihan dari ESP8266 adalah memilki deep sleep mode, sehingga penggunaan daya akan relatif jauh lebih efisien dibandingkan dengan modul Wifi lainnya. Modul ESP8266 dapat dilihat pada Gambar 15. Pada penelitian ini, modul ESP8266 digunakan sebagai modul komunikasi antara Arduino Uno dengan access point di sekitarnya. 


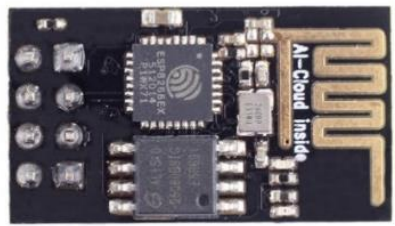

\section{Gambar 15 Modul ESP8266}

Teknologi lain yang digunakan adalah komputer server, tablet kasir, dan program POS. Komputer server digunakan untuk menyimpan data dan aplikasi berbasis web. Tablet berguna untuk menampilkan data hasil scan transaksi pelanggan pada daerah kasir. Program POS berbasis web yang ditampilkan pada tablet digunakan untuk menampilkan informasi dari setiap produk yang telah teridentifikasi pada layar, mengolah proses transaksi pembayaran dan menampilkan hasil transaksi.

Apabila ditinjau dari keseluruhan teknologi, seluruh peralatan tersebut dapat saling terintegrasi dan berhubungan dengan sistem dengan baik. Kelemahan yang dihadapi saat ini adalah belum tersedianya Active RFID tag dalam bentuk label tetapi dengan kemajuan teknologi di masa depan tidak menutup kemungkinan tag tersebut diciptakan dan tersedia.

Berdasarkan hasil wawancara terhadap responden maka dapat diperoleh kesimpulan bahwa penerapan teknologi RFID pada fungsi bisnis penjualan merupakan sebuah teknologi yang baru. Walaupun merupakan teknologi yang baru tetapi responden merasa bahwa prospek penerapannya di masa depan sangat baik. Nilai rata-rata tanggapan responden terhadap kelayakan teknik adalah sebesar 7.5.

\subsection{Kelayakan Economic}

Aspek economic atau finansial sangat memegang peranan penting dalam melakukan analisis kelayakan implementasi dengan melakukan pengkajian mengenai aspek-aspek pendapatan dan biaya yang diperlukan. Hal ini dimaksudkan sebagai bahan kajian pertimbangan tersendiri bagi pihak manajemen perusahaan dalam mengambil langkah strategis terhadap penyelenggaraan layanan bisnis.

Apabila manajemen memberikan indikasi bahwa pihak manajemen mendukung sistem tersebut, akan tetapi belum dapat menyediakan dana yang dibutuhkan maka penilaian kelayakan ekonomi antara 5 sampai dengan 8. Namun sebaliknya jika manajemen memilki dana untuk menerapkan sistem, maka penilaian kelayakan ekonomi antara 9 sampai dengan 10 (Syaifullah \& Widianto, 2014).

Untuk mengambil suatu keputusan dalam memilih suatu investasi diperlukan perhitungan dan analisis yang tepat untuk menilai dan menentukan investasi yang menguntungkan ditinjau dari segi ekonomis. Untuk mencapai sebuah gambaran investasi bagi pihak manajemen supermarket maka dijabarkan dan membandingkan harga dari perangkat kasir yang menggunakan teknologi barcode dengan perangkat kasir yang memanfaatkan teknologi $R F I D$, baik Passive maupun Active RFID.

Tabel 1 Pengadaan Mesin Kasir berbasis Barcode

\begin{tabular}{llcccc}
\hline \multicolumn{1}{c}{ Perangkat } & \multicolumn{1}{c}{ Spesifikasi } & Jumlah & $\begin{array}{c}\text { Perkiraan } \\
\text { Harga Satuan }\end{array}$ & \multicolumn{1}{c}{ Total Harga } \\
\hline Komputer & $\begin{array}{l}\text { Intel Core I3 3.2GHz, } \\
\text { DDR3 2 GB, HDD 500 }\end{array}$ & 4 & Rp. 3.800.000,- & Rp. 15.200.000,- \\
& $\begin{array}{l}\text { GB, DVD-RW, LCD } \\
\text { LED 16" }\end{array}$ & & & & \\
Mouse & Logitech B100 & 4 & Rp. 21.500 & Rp & $86.000,-$
\end{tabular}




\begin{tabular}{llcccc}
\hline \multicolumn{1}{c}{ Perangkat } & \multicolumn{1}{c}{ Spesifikasi } & Jumlah & $\begin{array}{c}\text { Perkiraan } \\
\text { Harga Satuan }\end{array}$ & \multicolumn{2}{c}{ Total Harga } \\
\hline Keyboard & Logitech K100 & 4 & Rp. 75.000 & Rp & $300.000,-$ \\
Printer Kasir & Postronix TX-250 & 4 & Rp. 1.875.000 & Rp $7.500 .000,-$ \\
Scanner & Postronix Scanner & 4 & Rp. 1.150.000 & Rp $4.600 .000,-$ \\
Laci Kasir & $\begin{array}{l}\text { Carcode Lasercode } \\
\text { Cash Drawer Postronix }\end{array}$ & 4 & Rp. 1.100.000 & Rp 4.400.000,- \\
Customer & Integra & Postronix WD-2029 & 4 & Rp. 1.550.000 & Rp 6.200.000,- \\
Display & & & & TOTAL & Rp 38.286.000,- \\
\hline
\end{tabular}

Tabel 2 Pengadaan Mesin Kasir berbasis Passive RFID

\begin{tabular}{|c|c|c|c|c|}
\hline Perangkat & Spesifikasi & Jumlah & $\begin{array}{c}\text { Perkiraan } \\
\text { Harga Satuan }\end{array}$ & Total Harga \\
\hline Komputer & $\begin{array}{l}\text { Intel Core I3 3.2GHz, } \\
\text { DDR3 } 2 \text { GB, HDD } 500 \\
\text { GB, DVD-RW, LCD } \\
\text { LED 16" }\end{array}$ & 4 & Rp. 3.800.000,- & Rp. 15.200.000,- \\
\hline Mouse & Logitech B100 & 4 & 21.500 & $86.000,-$ \\
\hline Keyboard & Logitech K100 & 4 & 75.000 & $\mathrm{Rp} \quad 300.000,-$ \\
\hline Printer Kasir & Postronix TX-250 & 4 & Rp. 1.875 .000 & Rp 7.500.000,- \\
\hline Laci Kasir & $\begin{array}{l}\text { Cash Drawer Postronix } \\
\text { Integra }\end{array}$ & 4 & Rp. 1.100 .000 & Rp 4.400.000,- \\
\hline $\begin{array}{l}\text { Customer } \\
\text { Display }\end{array}$ & Postronix WD-2029 & 4 & Rp. 1.550 .000 & Rp 6.200.000,- \\
\hline Arduino UNO & Board Model UNO R3 & 4 & 89.500 & $\mathrm{Rp} \quad 358.000,-$ \\
\hline RFID Reader & RFID-RC522 & 4 & 29.900 & Rp $\quad 119.600,-$ \\
\hline \multirow[t]{2}{*}{ RFID Tag } & $\begin{array}{l}\text { Square Paper, } 13.56 \\
\mathrm{MHz}\end{array}$ & 1.000 & 2.157 & Rp 2.157.000,- \\
\hline & & & TOTAL & Rp 36.320.600,- \\
\hline \multicolumn{5}{|c|}{ Tabel 3 Pengadaan Mesin Kasir berbasis Active RFID } \\
\hline Perangkat & Spesifikasi & Jumlah & $\begin{array}{c}\text { Perkiraan } \\
\text { Harga Satuan }\end{array}$ & Total Harga \\
\hline Tablet & $\begin{array}{l}\text { Tablet Quad Core 1.0 } \\
\text { Ghz, } 2 \text { GB RAM, 10" }\end{array}$ & 4 & Rp. 2.000.000 & Rp 8.000.000,- \\
\hline Printer Kasir & $\begin{array}{l}\text { Handheld Thermal } \\
\text { Bluetooth Wifi Printer }\end{array}$ & 4 & Rp. 1.300 .000 & Rp 5.200.000,- \\
\hline Laci Kasir & $\begin{array}{l}\text { Cash Drawer Mini } \\
\text { Securebox }\end{array}$ & 4 & Rp. $\quad 500.000$ & Rp $2.000 .000,-$ \\
\hline Arduino UNO & $\begin{array}{l}\text { Board Model UNO R3 } \\
+ \text { ESP8266 }\end{array}$ & 4 & Rp. $\quad 189.500$ & Rp $\quad 758.000,-$ \\
\hline RFID Reader & XD-RF & 4 & 50.000 & Rp $2.000 .000,-$ \\
\hline RFID Tag & Sticker/Tag, $315 \mathrm{MHz}$ & 1.000 & 25.000 & Rp 25.000.000,- \\
\hline
\end{tabular}




\begin{tabular}{|c|c|c|c|c|}
\hline Perangkat & Spesifikasi & Jumlah & $\begin{array}{c}\text { Perkiraan } \\
\text { Harga Satuan }\end{array}$ & Total Harga \\
\hline & & & TOTAL & Rp 42.958.000,- \\
\hline
\end{tabular}

Berdasarkan gambaran nilai investasi yang dibutuhkan oleh perusahaan untuk menerapkan RFID pada Tabel 1, Tabel 2, dan Tabel 3 dapat dilihat bahwa investasi untuk Passive RFID merupakan investasi yang paling rendah sedangkan investasi Active RFID merupakan investasi yang paling mahal. Walaupun investasi yang dikeluarkan untuk penerapan Passive RFID paling rendah tetapi kelemahan dari Passive RFID adalah jarak jangkauan dan kecepatan pembacaan yang kurang bagus. Sedangkan untuk Active RFID walaupun memiliki investasi yang paling mahal tetapi memiliki jangkauan dan kecepatan pembacaan yang cepat.

Hasil wawancara dengan manajer penjualan diperoleh bahwa secara nilai investasi layak untuk diterapkan tetapi untuk saat ini pihak perusahaan masih menggunakan sistem yang lama. Berdasarkan hal tersebut maka dapat nilai terhadap kelayakan ekonomi adalah sebesar 6.5.

\subsection{Kelayakan Legal}

Pada umumnya legalitas suatu proyek bukan menjadi sebuah masalah, sehingga penilaian kelayakan hukum dapat sangat mungkin diberikan nilai 10. Namun jika terdapat permasalahan hukum yang mengakibatkan manajemen berurusan dengan hukum, maka penilaian kelayakan hukum bernilai 9.5 (Syaifullah \& Widianto, 2014).

Dari segi legal atau hukum, penerapan RFID tidak memiliki hambatan dari segi aturan yang berlaku. Penggunaan teknologi yang bersifat umum dan mudah diperoleh memungkinkan tidak adanya permasalahan terkait hak cipta teknologi tersebut. Penerapan $R F I D$ pada fungsi bisnis penjualan secara kelayakan legal diberikan nilai 9.5.

\subsection{Kelayakan Operational}

Secara operasional, penerapan RFID mempengaruhi fungsi kerja dari pegawai kasir. Pegawai kasir yang sebelumnya bertugas sebagai penginput data belanja pelanggan akan bergeser menjadi melakukan pengecekan belanja pelanggan. Hal ini disebabkan karena penginputan barang belanja pelanggan secara otomatis terinput ketika tag RFID di barang belanja terdeteksi oleh reader RFID di komputer kasir.

Dengan adanya perubahan kerja tersebut, beban kerja pegawai kasir akan menjadi lebih berkurang. Beban kerja yang akan meningkat untuk saat ini akan terjadi pada pegawai gudang. Hal ini disebabkan karena pengkodean barang saat ini masih mengikuti standar barcode sehingga pegawai gudang akan melakukan penempelan tag RFID pada setiap item.

Berdasarkan hasil wawancara dengan responden dapat diperoleh kesimpulan bahwa secara operasional, aplikasi pendukung RFID dana bentuk POS mudah untuk digunakan dan memiliki prinsip kerja yang sama dengan sistem penjualan pada umumnya. Scoring kelayakan operasional dapat diberikan nilai 9.0.

\subsection{Kelayakan Schedule}

Penerapan RFID ditinjau dari aspek schedule atau jadwal sangat bergantung dengan pihak yang mengembangkan sistemnya. Pihak pengembang dapat secara internal, outsourcing, atau membeli produk jadi dari pihak ketiga. Secara umum, integrasi RFID dengan sistem POS yang digunakan pada perusahaan dapat dilakukan dengan perkiraan waktu 1 (satu) hingga 3 (tiga) bulan. Berdasarkan hasil wawancara terhadap manajer $I T$ dan ahli $I T$, perkiraan waktu yang diberikan cukup untuk mengembangkan dan mengimplementasikan sistem. Hal ini dikarenakan proses coding baik pada aplikasi pendukung dan alat pendukung RFID tidak memiliki kompleksitas yang tinggi. Nilai kelayakan jadwal dapat diberikan nilai 9.0. 


\subsection{Nilai Akhir Kelayakan TELOS}

Setelah dilakukan penilaian terhadap setiap faktor TELOS maka akan dilakukan perhitungan rata-rata terhadap setiap nilai faktor. Penilaian akhir untuk setiap faktor TELOS dapat dilihat pada Tabel 4. Pada Tabel 4, dapat dilihat bahwa nilai rata-rata akhir TELOS adalah sebesar 8.2 yang berarti penerapan RFID pada fungsi bisnis penjualan LAYAK untuk diimplementasikan dengan risiko pengembangan yang rendah.

\section{Tabel 4 Scoring TELOS}

\begin{tabular}{lc}
\hline \multicolumn{1}{c}{ Faktor } & Nilai \\
\hline Technical & 7.5 \\
Economic & 6.5 \\
Legal & 9.0 \\
Operational & 9.0 \\
Schedule & 9.0 \\
\hline \multicolumn{1}{c}{ RERATA } & 8.2 \\
\hline
\end{tabular}

\section{KESIMPULAN}

Kesimpulan yang diperoleh dari penelitian ini adalah penerapan RFID di masa depan layak untuk digunakan sebagai pendukung fungsi bisnis penjualan pada komponen ERP perusahaan ritel skala besar. Hal ini dapat dilihat dengan nilai akhir TELOS sebesar 8.2 yang berarti sistem layak untuk dikembangkan dengan risiko pengembangan cukup rendah. Tantangan yang mungkin dihadapi saat ini adalah belum adanya standar mengenai penggunaan RFID pada barang serta label untuk tag Active RFID belum tersedia di pasaran tetapi seiring perkembangan teknologi yang terus meningkat, hal ini dapat diatasi dengan pengembangan tag Active RFID dalam bentuk label serta perubahan paradigma labelling barang dari barcode ke RFID.

\section{UCAPAN TERIMA KASIH}

Penulis mengucapkan terima kasih kepada Direktorat Riset dan Pengabdian Masyarakat (DRPM) Kementerian Riset, Teknologi, dan Pendidikan Tinggi atas dukungan yang diberikan kepada penulis berupa bantuan dana penelitian dalam skema Penelitian Dosen Pemula.

\section{DAFTAR RUJUKAN}

Drljaca, D. P., \& Latinovic, B. (2018). Using TELOS for the planning of the information system audit. IOP Conference Series: Materials Science and Engineering. https://doi.org/10.1088/1757-899X/294/1/012022

Hall, J. A. (2011). Information Technology Auditing and Assurance. In Cengage Learning. James A. O'Brien, \& Marakas, G. M. (2017). MANAGEMENT INFORMATION SYSTEMS Tenth Edition. In McGraw-Hill Irwin.

Jechlitschek, C. (2013). A Survey on Radio Frequency Identification Trends. In Iab. https://doi.org/10.1007/978-3-8348-9728-2_2 
Justis, R. T., \& Kreigsmann, B. (1979). The Feasibility Study As a Tool for Venture Analysis. Journal of Small Business Management.

Pradipta, G. A. dkk. (2014). Sistem Check Out Kasir Pada Supermarket Grosir Dengan Menggunakan Passive RFID Technology. Seminar Nasional Teknologi Informasi Dan Komunikasi 2014 (SENTIKA 2014) Yogyakarta 15 Maret 2014.

R.T. White, G., Gardiner, G., Prabhakar, G., \& Abd Razak, A. (2007). A Comparison of Barcoding and RFID Technologies in Practice. Journal of Information, Information Technology, and Organizations (Years 1-3). https://doi.org/10.28945/142

Ruhi, U., \& Ghatrenabi, P. (2016). Experiential learning spaces for enterprise resource planning courses in business schools. Proceedings - 2015 5th International Conference on e-Learning, ECONF 2015. https://doi.org/10.1109/ECONF.2015.30

Syaifullah, S., \& Widianto, J. (2014). STUDI KELAYAKAN SISTEM INFORMASI AKADEMIK BERBASIS WEB PADA POLTEKES KEMENKES RIAU DENGAN MENGGUNAKAN METODE KELAYAKAN TELOS. Jurnal Sains Dan Teknologi Industri.

Tungadi, A. L., \& Lisangan, E. A. (2019). Simulasi Penerapan Active RFID pada Fungsi Bisnis Penjualan sebagai Komponen ERP pada Perusahaan Ritel. Seminar Nasional Komunikasi Dan $\quad$ Informasi $\quad 3, \quad 1-8$. https://jurnal.kominfo.go.id/index.php/snki/article/view/2622

Tungadi, A. L., Lisangan, E. A., \& Saputra, A. R. (2019). Simulasi Sistem Point of Sale Menggunakan Radio Frequency Identification Pada Perusahaan Ritel. TEKNOMATIKA, Jurnal Informatika Dan Komputer, 12(1), 1-7. https://ejournal.unjaya.ac.id/index.php/teknomatika/article/view/119

Verdi, Y. (2013). Pentingnya Sistem Enterprise Resource Planning (Erp) Dalam Rangka Untuk Membangun Sumber Daya Pada Suatu Perusahaan. Manajemen Informatika.

Winda. (2009). pengenalan rfid. Pemgenalan Radio Frekuensi Identification. 